\title{
Nigerian Elite and the Culture of Primitive Accumulation
}

\author{
Stanley Edebiri Egharevba PhD Fellow \\ Doctoral Student \\ Department of Political Science \\ University of Benin \\ Benin City \\ Nigeria \\ E-mail: stainlessfbj@yahoo.com \\ Tel: +234(0)7038913722
}

\author{
Friday Osaru Ovenseri-Ogbomo Ph.D (Corresponding Author) \\ Senior Lecturer \\ Economics, Banking \& Finance Department \\ Benson Idahosa University \\ Benin City \\ Nigeria \\ E-mail: fovenseri-ogbomo@biu.edu.ng \\ Tel: +2348075316610
}

Received: November 21, 2018

Accepted: November 27, 2018

Online Published: December 1, 2018

\begin{abstract}
Nigeria is endowed with vast human and material resources to engender development but it still continues to luxuriate within the confines of a top speed in reverse to oblivion. As its relics, neocolonialism has given birth to industrialization, urbanization and militarization of the political process which generally has created "sudden billionaires" on one end of the ladder (elected or appointed public officials) and extremely poor masses (unemployed graduates and depressed masses) at the other end of the ladder. This paper basically exposes the developmental retrogressive outlooks of the masses due to primitive capitalist accumulation by the few elites who have piloted the affairs of the nation.
\end{abstract}

Keywords: Elite, Primitive Capitalist, Rent-entrepreneur, Multilateral Imperialism.

\section{Introduction}

The Nigerian state is endowed with enormous human and material resource capabilities, sitting on a vast land area of $923,773 \mathrm{~km}^{2}$ with vast solid minerals reserve, wonderful vegetations and fertile soil for growing different agricultural produce. It has over 160 million people of diverse cultural backgrounds. Despite these paraphernalia of development, the basic visible feature or condition of the Nigerian state is an unprecedented poverty, decayed and decaying infrastructure, massive unemployment and underemployment which are worsened by social vices of varying magnitudes due to political self-aggrandizement.

Prior to the invasion by African colonizers which led to the amalgamation of the Southern and Northern protectorates of Nigeria in 1914, the separate Hausa, Yoruba and Igbo enclaves were hitherto known for their respective values, norms, etc. which were basically the beauty of society. There was close affinity with virtues that promoted good life as the leadership was exemplary and valued hard work was greatly encouraged. The displacement of the Nigerian prestigious culture was replaced by the twin devices of subjugation and exploitation of the colonized characterized by oppressive connotation of slave trade (Osah, Osundina, Ayim, Nwokocha \& Chioma 2014). 
In 1960, the concatenated Northern and Southern Protectorate of Nigeria gained political independence and became a Republic in 1963 with high hopes that came with freedom from subjugation and exploitation. The hopes were a far cry from reality as the state became an avenue to amass wealth. Chuke (2003) puts it that, the ranks of the foreign bourgeoisie who were expanded through multilateral imperialism nurtured the domestic comprador exploiters in Nigeria through the educational system, religious indoctrination, among others.

There is another sense in which politics under develops Nigeria. This is the use of political power for the accumulation of wealth...The wealthiest people in Nigeria are generally people who have acquired wealth through state power: by political corruption, by access to state contracts, agency rates or concessions such as import licenses - which does not usually involve them in direct productive activity.... (Ake, 1996: 29)

Rather than bringing about human and material development, the state became an instrument of transfer of the exploitative tendencies of the colonial masters to the "indigenous colonizers". Soon enough, the envisaged development became a mirage as the political structures and operations were turned into a fast moving vehicle for primitive capital accumulation through the assiduous cultivation of a mutually beneficial alliance between themselves (imperial powers) and the domestic bureaucratic bourgeoisie for the highly lucrative joint venture. It became a tool for the enemies who sought the soul of the masses to deepen their impoverishment mechanisms by enriching their personal estates, with the commonwealth.

In further buttressing this view, the postulation of Karl Marx (1818-1883) on the theory of Modern Capitalist Society that provided the paths to economic growth and societal development comes to mind. The centrality of the state as a prime factor in the Nigerian political economy cannot be overemphasized as the motion or direction of the processes of production, distribution and value allocation rests on its shoulders. The desire to engineer a collective mass action to engender development seems utopian as this process is continually scuttled by the state which according to Marx, is "... but a committee for managing the affairs of the whole bourgeoisie..., the form in which the individuals of a ruling class assert their common interest" (Engels, 1919). The state is a tool in the hands of the dominant class as epitomized in the handling of the production process. It was once stated by John Campbell - (a former American Ambassador to Nigeria between 1998 -2000) that those who hold power in trust for the people do not wish for a change, what they want is to constantly lay siege on power and impoverish the people. They use the centrality of the state to situate the directions of politics and constantly oppress the masses (Omoyibo, 2014).

\section{Understanding Primitive Accumulation}

The Concise Oxford Dictionary of Politics portrays primitive accumulation as the process which was used by Marx to describe the gathering together of commodities, gold and silver, and finally money by which nascent capitalism created the material base (through the systematic exploitation of labour, expropriation of resources, and colonial plundering) that facilitated its dominance in the economic and political spheres (McLean \& McMillan, 2003)

Similarly, primitive accumulation is seen as the obsessive-compulsive acquisition of money and other material possessions far beyond what is needed for dignified human existence (Anele, 2015). It is obsessive in the sense that they cannot stop the criminal act to keep acquiring what is deemed to be in the physical possession of someone who does not require a psychiatric attention.

In a related development, Ake (1978) tagged the conditioning process by which the few privileged in the society seize the means of production and reduce the vast majority of the people to selling their labour power as primitive accumulation.

3. Capitalist Accumulation: A Marxist Theorization

It was Marx's perception that the production of surplus is "the absolute law of the capitalist model", that most of the surplus value is reconverted into capital which on the one side has the capitalist and on the other side - the wage labourers (Ogbeide, 2017). He further opined that in all societies, the state is the coercive instrument of the property owning classes in that the state acts in the interest of the dominant class who controls the state machinery through their ownership of the means of production and distribution.

The Nigerian political and socio-economic practice or tradition today is a reflection or typical of the imperial capitalist bourgeoisie before independence. In the view of Chuke (2003), there are basically three strata which reflect this practice. They are: 
i. The first stratum which consist of the petty-bourgeois political parties from the 1960 to the present. This is in addition to their ministers, commissioners, chairmen and heads of industries, permanent secretaries and other bureaucratic elite in federal and state public services and traditional rulers (Obas, Obis and Emirs)

ii. The second stratum encompasses the unproductive and parasitic commercial, financial, industrial and contracting firms which are archetypal of the colonial era engrossed in the aggressive desire for wealth generation.

iii. The third stratum consists of officers of the armed forces and police who serve as agents of protective covers for the petty-bourgeoisie. This stratum's (officers') involvement in politics further aggravated the material miseries of the populace as they became agents of wanton capitalist accumulation.

There is no gainsaying the fact that the corruption that has encapsulated the criminalization of the Nigerian state is made obvious with certain indices which are typified in the disposition of the leaders which reflect socio-economic, cultural and economic directions in the body polity. For example, Nigeria is built to be a mono-cultural economy with a high degree of disproportionality in the sharing or distribution of the common patrimony where the centrality of the state speaks volume and institutional weakness at the apogee occasioned by political exploitation and marginalization. Egharevba (2010) prudently asserted that in the 1970s, the Malaysian government visited Nigeria (Edo State) to learn the rudiments of palm oil and kernel production; and purchased some seedlings. Today, Malaysia is the world's second largest producer of palm produce after Indonesia which Nigerian elite neglected in their quest for petro-dollar.

The majority of Nigerian elite do nothing for living other than government patronage and this has engendered value system distortion. The foregoing has been succinctly put in perspective by Charles Soludo (cited in Nyewusira, and Nweke, $2014: 645$ - 655) thus:

"in Nigeria, the excessive dependence on oil has compounded by the concentration of the commanding heights of the economy in the hands of Government. Government then became the fastest and cheapest means of making quick money, a rentier state emerged, intensifying the politics of 'sharing' rather than 'production'. This created a horde of 'rent-entrepreneur', that is 'Big men' without any productive source of livelihood except proximity to state power".

In the view of Ake (1996), "therefore politics is warfare and governance spoils of war..." This is further exacerbated by the cultural value of primitive accumulation of wealth in Nigeria where there is celebration of wealth as a precursor to the factors working against the war against corruption

4. Criminalization of the Nigerian State: Elite-Underdevelopment Nexus

Nigeria is a nation endued with all the paraphernalia of development but the basic visible feature or condition of the Nigerian state is an unprecedented poverty, decayed and decaying infrastructure, massive unemployment and underemployment which are worsened by social vices of varying magnitudes due to political self aggrandizement. It has been widely articulated that Nigeria is a top player on the global or international pitch of political robbery where she can score a hundred goal in a ninety minute game. It is even said that if there is world cup for political robbery (corruption), the Nigerian nation would always play at the finals. Primitive accumulation is a threat to democracy because it constitutes a deprivation as well as denial for the citizens who had expected democracy to wipe away their tears after many agonizing years under military dictatorship (Saliu, 2011).

Kew (2006) opines that the Nigerian government remains distant from serving the interest of its people. Ayittey (2006) asserts that the African state has evolved into a predatory monster or a gangster state that uses a convoluted system of regulations and controls to pillage and rob the productive class - the peasantry. It is common knowledge that heads of state, ministers and highly placed African government officials raid the African treasury, misuse their positions in government to extort commissions on foreign loan contracts, skim foreign aid, inflate contracts to cronies for kickbacks and deposit the loot in overseas banks. The very people who are supposed to defend and protect the peasants' interests are themselves engaged in institutionalized looting". It is indeed a paradox that those saddled with the common patrimony of the Nigerian state use it for personal gains thereby defying the essence of the social contract (Ayittey, 2006).

When the question of elite-underdevelopment nexus is raised, there is a tendency to scapegoat the followers as being part of the problem. Perhaps, this is due to the notion that the leaders in Nigeria are not from Mars because they 
come from our families, villages, etc. and are elected or selected from among the people. It has become a cliché that every country has the government it deserves. Further credence is given to this fact on the ground that in the electoral process, followers do not avail the right candidates the opportunity to win election to correct the incidences of bad governance. To place culpability where it is required, it is necessary to state that the citizens are conditioned to act in manners that further perpetrate the abysmal dispositions of the elites. The Poor people who take to social vices due to frustration are daily railroaded to prison while "Political robbers" who are rich and powerful are allowed to breathe the air of freedom. They are conferred with immunity or granted perpetual injunction restraining anti-graft agencies from investigating and prosecuting them.

The African state is basically the product of colonial construction owing to the abundance of natural resources. This is responsible for the expansionist drive and this was bequeathed to the African privileged few (elites) who use the state structure as a tool for all manner of corrupt dispositions with reckless abandon.

All the arms of government have become uninterrupted drain channels of public funds earmarked for developmental projects and this is further made worse by constitutional provision of immunity clause which provides a viable platform that shields criminals in 'governments uniforms' and their associates. Former civilian governors are on the list of top profile Nigerians indicted for money laundering, fraud and various other corrupt practices. Ekpebu (1996) aptly puts it that "in office, the politicians turned the government treasury into a large scale private gold mine. To remain in office, they used armed thugs to ensure better representation for their political parties and rigged elections in broad day light".

The few that are handling the apparatuses of the state machinery has massively transferred the common patrimony of the people to their private estates without recourse to the wellbeing of the general masses who are supposed to be the raison d'être for their being selected, elected or appointed. Development is grossly impeded as hunger becomes the closest companion to the masses. This is aptly captured by Ake (1993) who emphasized that the colonial state which is the relics of colonial subjugation which by virtue of its violent and arbitrary disposition suppressed and exploited the colonial territory, could neither appreciate nor incorporate the captives' cultures, policy and experience into the emergent state system.

In Nigeria, the incapacitation in introducing or reacting quickly in a positive way to the plight of the masses is hinged on the long term and short term pretentious use of public office where the interest of the public officers are pursued with incalculable zeal while creating the impression that they are busy about issues of urgent national importance (Omoyibo, 2014). To assure them of maximal perpetration, they build patron-client networks which gives credence to their continuous perpetuation.

In corroboration, Garba 1995 (cited in Omoyibo, 2014 : 27) opined,

"in a country like Nigeria where the prizes are so few, and the stakes so high, the fight for booty or 'national cake' is fierce and often vicious. It has at times led to a debilitating corruption in the arena of public policy making and implementation. 'Who gains, who loses in these federal, state and local policy arenas is rarely an accident more often than not, the distributional consequences of public policies are the intended result of the private interests which have been instrumental in their design, passage, and implementation'.

Since 1960 in Nigeria, elections have become wars and the military abandoned their constitutional responsibility of defending the territorial integrity of a nation by developing a strong notch for politics. At the announcement of a military take-over of power, they suspend the functionality of the constitution. The legal mechanism which proposes punishment for ills of society is put in abeyance. This affords them of 'back door legality' to deflate the nation's treasury as corruption is institutionalized. The arrival of military juntas in the Nigerian polity saw the legitimization of the official bleeding of the treasury blood of the system. The 1975 Great Purge of the civil service by the Murtala Mohammed / Olusegun Obansanjo Regime which without recourse to lay down procedures as it relates to years of service, etc. retired civil servants. In the perspective of Agbo (2010), in Nigeria, we inhale and exhale corrupt air, feed on corrupt foods and we are frequently surrounded by elements of corruption.

Since the first military takeover on 15th January, 1966, the frequently adduced excuse for incursion in politics is 'neophytically' anchored on the pretense of 'correcting the massive corruption of the previous' but the reality proves otherwise as the actions of the military betray its declared intentions. In actual sense, the lands and seeds for and of corruption are cultivated and propagated the most by the military who openly pluck the fruits of good life whether they are mature or not (Osah, et al, 2014).

The eight years reigns of Gen. Ibrahim B. Babangida and Gen. Sani Abacha were characterized by massive stocking of the nation's common patrimony abroad. For instance, Gen. Babangida's regime was known for open collection of 'kick-backs and ten-percent' from all quoted contracts. It is also on record that the Halliburton bribe which indicted 
the military regimes of General Sani Abacha, General Abdulsalami Abubakar and the civilian administration of Olusegun Obasanjo are just a few of the heinous cases in high places (Osah, et al, 2014).

Since the discovery and beginning of oil exploration in Oloibiri in 1958, Nigeria has made over $\$ 500$ billion from crude oil sales. With reference to the parlous nature of the country, it is obvious that a very large chunk of the said money has been mismanaged by military dictators and selfish politicians (members of the ruling elite entrusted with the power to manage our resources) who have milked the nation dry (Anele, 2015).

Table 1: Selected fraud cases involving top government officials in Nigeria 2006-2015

\begin{tabular}{|c|c|c|c|}
\hline $\mathbf{S} / \mathbf{N}$ & Suspects & Year of Prosecution & Allegation \\
\hline 1. & $\begin{array}{l}\text { Peter Odili, former } \\
\text { Rivers State governor, }\end{array}$ & 2006 till date & $\begin{array}{l}\text { Accused of laundering and } \\
\text { Diverting over } \$ 100 \text { billion }\end{array}$ \\
\hline 2. & $\begin{array}{l}\text { Ayo Fayose, Ekiti State } \\
\text { Governor }\end{array}$ & 2006 till date & $\begin{array}{l}\text { Accused of stealing } \$ 400 \\
\text { Million }\end{array}$ \\
\hline 3. & $\begin{array}{l}\text { Saminu Turaki, ex governor } \\
\text { of Jigawa State }\end{array}$ & 2007 till date & $\begin{array}{l}\text { Accused of money } \\
\text { laundering, } \\
\text { misappropriation of } 36 \text { billion }\end{array}$ \\
\hline 4. & $\begin{array}{l}\text { Muhammed Goje, } \\
\text { ex governor of Gombe }\end{array}$ & 2011 till date &  \\
\hline 5. & $\begin{array}{l}\text { Chimaroke Nnamani, } \\
\text { former Enugu State } \\
\text { governor }\end{array}$ & 2011 till date & $\begin{array}{l}\text { Accused of money } \\
\text { laundering of about } \\
\quad 4.5 \text { billion } \\
\end{array}$ \\
\hline 6. & $\begin{array}{l}\text { Gbenga Daniel, } \\
\text { ex-Ogun State governor }\end{array}$ & 2011 till date & $\begin{array}{l}\text { Accused of money } \\
\text { laundering to the tune } \\
\text { of } \$ 211.3 \text { million }\end{array}$ \\
\hline 7. & $\begin{array}{l}\text { Murtala Nyako, } \\
\text { ex-Adamawa State } \\
\text { governor }\end{array}$ & 2014 till date & 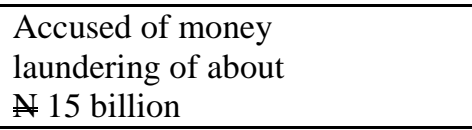 \\
\hline 8. & $\begin{array}{l}\text { Adebayo Alao-Akala, } \\
\text { ex-Oyo State governor }\end{array}$ & 2011 till date & $\begin{array}{l}\text { Accused of mismanagement } \\
\text { of funds up to } 11.5 \text { billion }\end{array}$ \\
\hline 9. & $\begin{array}{l}\text { Orji Uzor-Kalu, ex } \\
\text { Abia State governor }\end{array}$ & 2007 till date & $\begin{array}{l}\text { Accused of corruption, } \\
\text { money laundering to } \\
\text { the tune of } 5 \text { billion }\end{array}$ \\
\hline 10 . & $\begin{array}{l}\text { Joshua Dariye, former } \\
\text { Plateau state governor }\end{array}$ & 2007 till date & 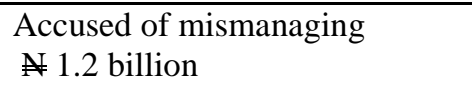 \\
\hline 11. & $\begin{array}{l}\text { Colonel Sambo Dasuki } \\
\text { (Rtd) former National } \\
\text { Security Adviser }\end{array}$ & 2015 till date & $\begin{array}{l}\text { Accused of money laundering } \\
\text { and breach of public trust } \\
\text { to the tune of } \$ 2.1 \text { billion }\end{array}$ \\
\hline
\end{tabular}

Source: Uche-Okobi 2015:17; Ajayi, 2015

\section{Conclusion and Recommendation}

Africa and indeed Nigeria had a very close tie with virtues that enhanced good life before the coming of the colonial masters. But this was bastardized by the colonial master's desire for cheap source of raw materials, labour, lucrative market and vast expanse of land aptly available for expropriation which replaced the exemplary and valued hard work virtues. Handing over political power to indigenous leaders who had copied this pattern of leadership further exacerbated the ills as the leadership became the twin devices of subjugation and exploitation, characterized by aggressive looting of the common patrimony of the masses with a reckless abandonment which manifested in the dehumanization of the people. Without recourse to the position of the law of the land, the common patrimony or commonwealth of the people is siphoned by the Nigeria ruling class through the process of primitive capital accumulation. 
Winning the war on corruption would require strict adherence to Obasanjo's slogan of 'no sacred cows' where this will not be mere words as the big wigs (elite) who are involved in primitive capital accumulation are adequately sanctioned (Aluko, 2009).

For Nigeria to experience development which is the yearning of the masses, corruption should not be condoned under any guise. Government must not be seen to pay lip service to the incidence of corruption. Government must be endowed enough to exercise a viable political will power to appropriately handle corrupt officials. The former president of United States of America (Barack Obama) once opined that the problem of Africa (and indeed Nigeria) is weak institution. Nigeria will need to build viably strong institutions where rules are aptly and stridently followed. Also, the anti-graft agencies must be strengthened adequately in order to function maximally.

The judiciary must be strengthened and closely monitored. It is indeed a ridicule of maximal propensity for an upright judge to sentence John Yakubu Yusuf (an assistant director in the Federal Service) who was accused together with six others of stealing N32.8 billion from the Police Pension Fund to two years imprisonment with an option of a fine of N750,000.00 which he gave without looking back. The judiciary must be watched because until the sanction for wrong doing outweighs its benefits, the temptation for aggrandizement of public fund becomes too pleasant to overcome.

Party affiliations must be expunged when dealing with corrupt cases. The character of favoritism and nepotism on the part of government must be seriously checked to avoid the recruitment of mediocre. Sensitive positions should not be used as a political compensation mechanism. Square pegs should used in square holes.

Also, government should not be seen as an instrument of primitive accumulation. Rather the principle of servant leadership must be imbibed and value reorientation must be encouraged. Citizens' mental and value re-orientation is sacrosanct. Assist in building our depreciated value system where it has become a crime to be in a political position without misappropriating public funds. We should not celebrate our family members who got into politics to siphon money for people oriented projects thereby impoverishing the populace.

\section{References}

Agbo, A. (2010). Tell magazine of November, 8

Ajayi, O. (2015, December 3). \$2.1 bn Arms deal: I didn’t receive a dime from Dasuki, says ex-Gov. Bafarawa. Vanguard. Retrieved from http://www.vanguardngr.com/2015/12/03/2-1-bn-arms-deal-i-didnt-receive-adime-from-dasuki-says-ex-gov-bafarawa/

Ake, C. (1978). Revolutionary Pressures in Africa. London: Zed Press Ltd.

(1996). Social Science as Imperialism: The Theory of Political Development, University Press Ibadan, Nigeria.

Aluko, Y. A. (2009): Corruption in Nigeria: concept and Demission in Anti-Corruption Reforms in Nigeria since

1999: issues, challenges and the way forward IFRA special Resources issues, vol. 3.

Anele, D. (2015). The absurdity of Primitive Accumulation. Retrieved on August $22^{\text {nd }}$,

2017, available at http://www.vanguardngr.com/2015/07/the-absurdity-of-primitive-accumulation/

Ayittey, B.N.G. (2006) Nigeria's struggle with corruption (A testimony before the Committee on International Relation's Subcommittee on Africa, Global Human Rights and International Operations House Committee on Africa, U.S. House of Representative) Washington, D. C, Thursday, May 18

Campbell, J. (2010). Nigeria: Dancing on the Brink. Ibadan: Bookcraft

Chuke, P. I. (2003). Political Economy: Fundamental Notes. Benin: Wilprint Publications

Egharevba, E. S. (2010). Challenges to Destiny, Offa, Kwara state: Supreme Print Solutions

Engels, F. (1919), Basic Writings on Politics and Philosophy. New York: Doubleday (Anchor Books), 17, Pg. 27

Garba, J. (1995). Fractured History: Elite Shifts and Policy Changes in Nigeria; Princeton: Sungai books; Pg. 294

Kew, D. (2006) Nigeria in Sarja (ed.) Countries at the Crossroads (New York: Freedom House)

McLean, I. and McMillan, A. (2003). The Concise Oxford Dictionary of Politics, second edition. Oxford: Oxford University Press.

Nyewusira, V. and Nweke, K. (2014). Nigeria and the Attainment of Sustainable Development in the $21^{\text {st }}$ Century, Mediterranean Journal of Social Sciences MCSER Publishing, Rome-Italy Vol. 5, No 4

Omoyibo, K. U. (2014). "Marxism and the Nigerian State", European Scientific Journal May Edition vol. 8, No.11, Pg. $20-33$ 
Osah, G., Osundina, O., Ayim, O., Nwokocha, C. and Chioma, P. (2014). "The Political Economy of Corruption and Leadership in Nigeria", Arabian Journal of Business and Management Review. Vol. 3, No.8.

Saliu, H. A. (2011) "Challenges of Democracy in Nigeria and the Pathways" in Nigerian Forum, Nigerian Institute of International Affairs. July - August, 2011 Pg. 227-238

Soludo, C. (2005). "The Political Economy of Sustainable Democracy in Nigeria". The 5th Nigeria Democracy Day Lecture Delivered on May 29th, in Abuja.

Uche-Okobi, J. (2015, April 17). The Burden of Corruption in Tell Corruption Governors Waiting for Buhari, 17, $14-22$.

\section{Copyrights}

Copyright for this article is retained by the author(s), with first publication rights granted to the journal.

This is an open-access article distributed under the terms and conditions of the Creative Commons Attribution license (http://creativecommons.org/licenses/by/4.0/) 